\title{
Independence and impartiality of sports disputes resolution in the UK
}

\author{
Leanne O'Leary $^{1}$ (1) \\ Accepted: 26 May 2021 / Published online: 10 June 2021 \\ (c) The Author(s) 2021
}

\begin{abstract}
"...even appearances may be of a certain importance or, in other words, 'justice must not only be done, it must also be seen to be done'. What is at stake is the confidence which the courts in a democratic society must inspire in the public."1
\end{abstract}

Private sports governing bodies in the United Kingdom have the contractual freedom to organise their own sports tribunals and disputes procedures. There is no legislation in the UK that governs the form of a sports governing body's dispute resolution procedure. The common law and, to a certain extent, other industry measures influence the structure of a disputes procedure within a private sports governing body. When establishing dispute resolution systems in self-regulating industries, there is potential for structural conflicts of interest to arise. Reporting mechanisms and adjudicatory processes may be structurally bias through, for example, the way appointments are made to a dispute resolution panel. There may be the suggestion of implicit bias of panel members because of the interests that control the appointment process. Even if no actual bias arises, the perception of bias can damage the engagement of stakeholders in a dispute process and damage the reputation of the sport with sponsors or the general public. The key is to minimise structural conflicts of interest and ensure that the process is independent and impartial. This article examines the challenges faced with organising sports dispute resolution procedures, the requirements of Article 6 of the European Convention on Human Rights and highlights the important factors that a sports governing body should consider when designing an independent and impartial dispute resolution system. It concludes with a discussion of whether the legal basis for sports dispute resolution in the UK requires reconsideration to provide certainty, independence, impartiality and, above all, to guarantee a fair hearing.

\section{Introduction}

There are different models of sports dispute resolution systems in the United Kingdom (UK). Dispute procedures will also be found in athletes' contracts or the constitutional documents of sports leagues. It is a fragmented dispute resolution system and procedures differ between sports. Some sports governing bodies may use arbitration as a dispute resolution procedure; ${ }^{2}$ a few encourage mediation. Some refer disputes to Sport Resolutions UK, a private dispute resolution service that administers investigations, appoints panels to hear disputes and case manages proceedings to provide an

Leanne O'Leary

olearyl@edgehill.ac.uk

1 Edge Hill University, Ormskirk, UK independent sports dispute process. Howsoever organised, in the regulatory model of sport favoured in the UK, a dispute resolution system will be enshrined in a sport's regulatory framework and those who participate in the sport, whether amateur or professional, athlete, volunteer, coach, umpire or club, will be subject to the sport's rules and procedures as a condition of participation.

There is no legislation in the UK that governs the form of a sports governing body's dispute resolution procedure. ${ }^{3}$ Instead, the common law and, to a certain extent, other

\footnotetext{
${ }_{1}$ Mutu and Pechstein v Switzerland App nos 40575/10 and 67474/10 (ECtHR, 2 October 2018), para 143.

2 See, for example: Rule K Agreement to Arbitration in The Rules of the Association, Part X of the FA Handbook 2019/2020); England and County Cricket Board, Cricket Discipline Commission Regulations, regulation 10 Appeals Procedure; and clause 14 of the approved Boxer/Manager Agreement by the British Boxing Board of Control (BBBC) and regulations 24, 26 and 28 of the BBBC Rules and Regulations.

${ }^{3}$ Only a few countries have enacted national legislation that underpins a tribunal or forum independent of a sport's regulatory framework to resolve disputes in the sports sector. See, for example: The Sports Tribunal of New Zealand established under the Sports AntiDoping Act 2006 (NZ); the Sport Dispute Resolution Centre of Canada established under the Physical Activity and Sport Act (Canada); and the National Sports Tribunal in Australia: National Sports Tribunal Act 2019.
} 
industry measures may influence the form of a dispute resolution structure within a sports governing body. Examples of other measures include good governance principles and the requirements of the World Anti-Doping Code. ${ }^{4}$ National good governance initiatives in the UK focus on the regulatory decision-making process (of which establishing a dispute resolution system is a part) and the financial aspects of a sport's administration, although none refer to, or offer guidance on, the minimum standards required of a sports dispute resolution procedure. Designing a dispute resolution system independent of a sports governing body should be a routine part of good governance practices in sport; it may even need to be supported by a requirement under national legislation.

The dispute resolution procedures in the sports industry deal with a breadth of disciplinary matters and other disputes, ranging from a complex match-fixing allegation or safeguarding issue to a straightforward contract dispute. Some disputes may be of high monetary value, involve a determination of someone's continued participation in the industry or touch on sensitive issues that also form the basis of a criminal prosecution. Some disputes may be of little monetary value. Sports disputes also attract media attention that can bring additional pressures on processes and for those involved in them. Organising an independent dispute resolution system can be costly for some sports, even with the assistance of volunteers. There may also be concerns about resourcing or the expertise to investigate disciplinary cases, particularly cases involving sexual abuse or matchfixing. ${ }^{5}$ It is important, therefore, that a dispute resolution procedure, whether regulatory or contractual, has the appropriate procedural safeguards in place to balance the interests and rights of all involved.

It is not unusual for a self-regulating industry to police itself; in fact, it is expected. ${ }^{6}$ However, in self-regulating industries such as the sports industry, there is potential for structural conflicts of interest to arise. Reporting mechanisms and adjudicatory processes may be structurally bias through, for example, the way appointments are made to

\footnotetext{
${ }^{4}$ See the UK Sport Code of Sports Governance available on the UK Sport website at < https://www.uksport.gov.uk/resources/gover nance-code>; Sport and Recreation Principles of Good Governance <https://www.sportandrecreation.org.uk/governance/the-princ iples-of-good-governance>; and World Anti-Doping Code International Standard Result Management (January 2021), sections 8 and 10 that require first instance anti-doping offences to be heard before an operationally independent tribunal and appeals to be held before an institutionally independent tribunal. Note also principle 7 of the EU Good Governance Principles compiled by the Working Group on Good Governance that was a part of the European Union (EU) Working Plan for Sport, in October 2013.

5 MA Weston (2017) 445.

6 J Black (1996).
}

a dispute resolution panel. There may be a suggestion of implicit bias of panel members because of the interests that control the appointment process. Even if no actual bias arises, the perception of bias can damage the engagement of stakeholders in a dispute process and the reputation of the sport with sponsors or the general public. There is a broader public interest of ensuring that athletes, volunteers and others who are subject to a sports governing body's regulation have an independent and impartial disputes resolution system that is fair. The key is to minimise the structural conflicts of interest that can arise and to ensure that the process is independent and impartial.

This article examines the requirements for an independent and impartial dispute resolution system in the sports industry. It commences with a discussion of the challenges faced with organising sports dispute resolution procedures, considers the requirements of Article 6 of the European Convention on Human Rights (ECHR) and highlights the important factors that a sports governing body should consider when designing an independent and impartial dispute resolution system. Finally, it concludes with a discussion of whether in light of the recent decisions of the European Court of Human Rights (ECtHR) in Mutu and Pechstein v Switzerland ${ }^{7}$ and Ali Riza and Others v Turkey, ${ }^{8}$ sports resolution procedures in the UK should be underpinned by statute.

\section{The challenge of dispute resolution design in the sports industry}

Private sports' governing bodies in the UK have the contractual freedom to organise their own sports tribunals and disputes procedures. If the system is set up as an arbitration procedure, then the procedure will be supervised by the Arbitration Act 1996. If the system is not an arbitral procedure, then in England and Wales, the supervisory jurisdiction of the High Court has oversight of sports disciplinary decisions. ${ }^{9}$ Alternative dispute resolution is favoured as a mechanism for resolving disputes in the sports industry. Those with industry expertise can be appointed to adjudicate, resolution is generally quick and costs are relatively low (although with some disputes where the loss of economic rights is high, costs may escalate and the matter take time to resolve).

\footnotetext{
7 App nos 40575/10 and 67474/10 (ECtHR, 2 October 2018).

8 App nos 30226/10 and 4 Others (ECtHR, 28 January 2020).

${ }^{9}$ See Flaherty v National Greyhound Racing Club Ltd [2005] EWCA Civ 1117; Bradley v Jockey Club [2005] EWCA Civ 1056; and Modahl v British Athletic Federation Ltd (No 2) [2002] 1 WLR 1192 (CA).
} 
Alternative dispute resolution processes are normally voluntary. There is a commonly held view that the parties to a voluntary dispute resolution process may be more satisfied with the outcome, have stronger feelings of procedural justice and control over the process, with a consequential benefit to post-settlement compliance and in respect of ongoing relationships, a more durable relationship than when a resolution is imposed. ${ }^{10}$ Research into the issue of voluntary dispute resolution processes as compared to imposed dispute resolution processes is limited and the superiority of a consensual process when compared to a non-consensual one is not universally accepted. ${ }^{11}$ Nonetheless, whether voluntary or not, the parties' perception of a process' fairness is important. ${ }^{12}$

Structural conflicts of interest can arise when designing and implementing a sports dispute resolution system if there is insufficient separation of powers between those who adopt the rules, investigate allegations and appoint adjudicators to hear the issue. Sports dispute resolution systems have typically developed organically under the control of a sports governing body. There may be a lack of resources and knowledge within the governing body on how to establish an independent and impartial dispute resolution system. Challenges to the fairness of a disciplinary or dispute procedure may require legal proceedings to be brought through the courts. However, many disciplinary proceedings or sports disputes involve volunteers or amateurs who may be reluctant to challenge the dispute through the general court system (if in fact it is permitted under the sport's rules), when the costs of a legal challenge are taken into account. Also, the dispute may not involve large sums of money to be cost effective to challenge the system, even if there are important substantive and procedural rights at issue.

On the occasion where proceedings have been brought before a general court, the courts have shown judicial deference to a sports tribunal's decision (which is not uncommon in relation to other industry tribunal or disciplinary panel decisions). ${ }^{13}$ The courts recognise that sporting bodies should be given, "as free a hand as possible, consistent with the fundamental requirements of fairness," 14 to organise their own disciplinary procedures without the interference of the courts. Sports panels have expertise and knowledge of the industry that usually place it in the best position to determine a sports dispute at first instance, and accordingly the courts provide a tribunal with a generous margin of

\footnotetext{
$\overline{10}$ See summary in JW Budd, A Sojouner and J Jung (2017), 865.

11 Ibid 867.

12 Ibid.

13 For a discussion, see S Boyes, (2017).

14 Flaherty v National Greyhound Racing Club Ltd [2005] EWCA Civ 1117, para 78.
}

appreciation in their decision-making. Nonetheless, while the courts appreciate that a sports tribunal has considerable expertise, there is recognition that "unthinking servile obeisance" 15 to a sports tribunal's decision is not appropriate, particularly where the decision under challenge affects a person's livelihood. ${ }^{16}$ Furthermore, recent judgements show the willingness of the courts to intervene when imbalances of power arise in certain contractual relationships, particularly employment relationships. ${ }^{17}$ A panel appointed by a sports governing body may be well-suited to determining the substance of industry disputes, but the structure and legal form in which the decision is made must still comply with the law.

Independence and impartiality are the hallmarks of a fair judicial process and also the rule of law. ${ }^{18}$ The independence of the process secures the impartiality of the tribunal or adjudicative forum in the minds of tribunal members and the public. ${ }^{19}$ Independence refers to the absence of any connection between the tribunal or adjudicator and the executive or regulatory body that adopts, implements and enforces the rules. It also encompasses the ability of the adjudicator to form a view of the facts and reach a decision uninhibited by the influence of the structure or organisation around it. The extent to which structural independence of a judicial system is secured in a sports governing body depends on: the willingness of a private sports governing body to relinquish control of the judicial function; the ability of other stakeholders to influence the structural form of the system; and the law.

Establishing an independent disciplinary and dispute mechanism is important for the legitimacy of sport as a self-regulating industry. Procedural justice is premised on the notion that the legitimacy of authorities to govern is based upon the fairness of procedures used rather than the substance of their decisions. ${ }^{20}$ People may be more willing to accept a decision voluntarily when the decision made is fair. ${ }^{21}$ Four elements contribute to judgements about the fairness of a procedure, namely: the opportunity to participate in the decision-making process; the neutrality of the authority's decision-making process; the degree to which a person is treated with dignity and respect; and the cues that communicate information about the

\footnotetext{
${ }^{15}$ McKeown $v$ British Horseracing Authority [2010] EWHC 508 (QB), para 37.

16 Ibid.

${ }^{17} R$ (on the application of UNISON $v$ Lord Chancellor [2017] UKSC 51; Autoclenz Ltd v Belcher [2011] ICR 1157; "It can no longer be said that Judges 'turn a blind eye' to the inequalities that abound in employment relationships": A Bogg, (2018) 519.

${ }^{18}$ L Neuberger, (2015)

19 Gillies v Secretary of State for Work and Pensions [2006] 1 WLR 781 (HL), para 38.

20 TR Tyler (2009) 187.

21 T Tyler (2000) 119.
} 
intentions and character of legal authorities with whom they are dealing - i.e. trustworthiness. ${ }^{22}$

Owing to the historical development of sports governing bodies, some sports' dispute resolution systems have been designed without consideration of the views of stakeholders who may be subject to the process. Designing a dispute resolution system that does not consider the views of those who are subject to it, may lead to criticism about the legitimacy of the process and problems with stakeholder "buy-in". The opportunity to have the perspective of athletes, clubs, volunteers and others who are subject to the procedure involved in the procedure's design or included on panels; the independence and impartiality of those making the decision; the degree with which the parties are subject to dignity and respect throughout the process; and the trustworthiness of those involved, all contribute to the perception of a fair dispute resolution process and legitimise the governing body's position in the industry.

The form of a disciplinary or disputes procedure, the forums which adjudicate the complaint, whether the forum is established as an arbitral tribunal or not, and who adjudicates cases, may be determined during the regulatory decision-making process. The extent to which stakeholder groups are consulted regarding the form of that procedure or the judicial structure will depend on the power and influence of stakeholder groups within the regulatory body. Historically, certain stakeholder groups have not been represented in sports regulatory decision-making processes and although it may be improving in some sports, it is difficult to gauge how these groups (for example, athletes, coaches or volunteers) have influenced the form and content of regulatory dispute resolution systems, if at all. Establishing the adjudicatory structure as an arbitral process which limits the court's review of the process to that permitted under national arbitration law, can also be problematic. It is generally thought that arbitration can be used to circumvent the protection of individual rights afforded by national law. ${ }^{23}$ It may also be viewed as inherently bias in favour of

\footnotetext{
22 Tyler (n 20) 187-188; NH Rogers, (2013)

${ }^{23}$ Neuberger (n 18) 278. Note that the public policy exception to enforcing foreign arbitral awards can play a role in ensuring that fundamental rights are maintained. See for example: Marco van der Harst, "Enforcement of CAS Arbitral Awards by National Courts \& the Effective Protection of EU Law" in C Paulussen et al (eds) Fundamental Rights in International and European Law TMC Asser Press, The Netherlands 2016) chapter 12; A Rigozzi, (2010), 251; and Matuzalem v Fédération Internationale de Football Association Case No 4A_558/2011 (Swiss Federal Court, 27 March 2012). See also the European competition law challenge to the International Skating Union's Eligibility Rules that alleges that a requirement to submit to arbitration reinforces the restriction of an athlete's commercial freedom under European competition law: European Commission Decision of 8 December 2017 Case AT 40208 International Skating Union's Eligibility Rules; appeal partially upheld in Case T-93/18 International Skating Union v European Commission [2021] 4 CMLR 9; appeal pending to the Court of Justice of the European
}

a governing body's interests. According to Lord Neuberger, "any increase in freedom or power carries a concomitant increase in responsibility and an increase in arbitral powers must be accompanied by an increased responsibility to observe fundamental rights." 24

Article 6 of the ECHR is incorporated into national law in the UK through the Human Rights Act 1998 (HRA 1998) and affords a person the right to a fair hearing in an "independent and impartial tribunal established by law". At common law, the principles of natural justice, specifically nemo iudex in sua causa (no judge should be a judge in his/her own cause), are also applicable to establishing requirements of independence and impartiality in any developed system of justice. The following section considers the application of Article 6 to sports dispute resolution procedures in the UK.

\section{Article 6 of the European Convention on Human Rights: the right to a fair hearing}

At first glance, it may appear that a tribunal or panel whose jurisdiction is established under contract by a private sports governing body, is not subject to the ECHR. The ECHR was primarily enacted to control abuse of power by organs of the State. It is incorporated into national law through the HRA 1998 and applies to public authorities—as that term is defined in $\mathrm{s} 6$. It does not apply directly to sports governing bodies because these organisations are currently viewed as private entities. ${ }^{25}$ The ECHR, however, has indirect effect; the HRA 1998 will apply even though a sports governing body is not viewed as a public authority because pursuant to s 6(3)(a) of the HRA 1998, the courts are required to act in a way that is compatible with an ECHR right. The court will be required to give effect to ECHR rights in a claim that challenges the substantive and procedural fairness of a sports tribunal process.

Even if a first instance tribunal does not comply with Article 6, then Article 6 may be satisfied so long as proceedings are subject to a review by a judicial body that does comply with Article 6 and has full jurisdiction to consider the law and the facts. ${ }^{26}$ The ECtHR's position is that it is the totality of the procedure that is important for compliance with Article 6. The courts will consider whether the internal

\footnotetext{
Footnote 23 (continued)

Union C-124/21 P International Skating Union v European Commission.

${ }^{24}$ Neuberger (n 18) 278.

25 See, for example, $R v$ Disciplinary Committee of the Jockey Club, ex parte Aga Khan [1993] 1 WLR 909 (CA), a case decided in the context of a judicial review claim.

${ }^{26}$ Riepan v Austria App no 35115/97 (ECtHR, 14 November 2000), para 39; Gautrin v France (1999) 28 EHRR 196, para 58.
} 
disciplinary proceedings at issue produced a fair result or whether the defects that have infected the process have led ultimately to an unfair result. Overall, Article 6 will apply to sports dispute resolution proceedings unless the parties have agreed to waive its application, for example, through voluntary arbitration.

Article 6(1) guarantees the right to a fair hearing before an independent and impartial tribunal established by law. It has a civil and criminal limb and when considering challenges to a sports tribunal, the civil limb is relevant. To engage the civil limb of Article 6, a dispute at a national level is required between two private individuals-or an individual and the state-the outcome of which must be determinative of the applicant's civil rights and obligations. In disciplinary proceedings, the ECtHR has previously held that disputes regarding the right to practise a profession give rise to disputes over civil rights and obligations. ${ }^{27}$ In the sports context, in Ali Riza and Others $v$ Turkey, ${ }^{28}$ the ECtHR declared inadmissible applications brought by three amateur football players against the Turkish Football Federation (TFF) on the basis that their dispute was not "pecuniary" in nature and did not involve the determination of a civil right or obligation. ${ }^{29}$ Since the amateur football players were unable to demonstrate that they earned a living from playing football, their dispute with the TFF did not have a pecuniary element and they were unable to challenge the one-year suspension confirmed in the course of disciplinary proceedings before the Turkish Football Federation Arbitration Committee (TFF AC), an entity that the footballers claimed lacked independence and impartiality under Article 6(1).

Following Ali Riza, it may appear that all disputes involving amateur athletes now fall outside the scope of Article $6(1)$, with the practical effect that a lesser standard of procedural guarantees may apply to dispute resolution systems that involve amateur athletes than those that involve professional athletes. The disciplinary cases considered by the ECtHR have in the main related to lawyers, doctors or regulatory entities that control entry into a profession for the purposes of earning a living only. Sports governing bodies regulate participation for professional and amateur athletes, the latter of whom generally participate in organised sport for recreational purposes and/or are defined as amateur under the sport's rules. Whether an athlete is amateur or professional and the legal rights that attach to the status has

${ }_{27}$ Le Compte, Van Leuven \& De Meyere v Belgium (1981) 4 EHRR 1, para 48; Ali Riza (n 8) para 155.

28 Ali Riza (n 8).

29 Ali Riza (n 8) paras $155-156$. been a longstanding argument raised in sports disputes. ${ }^{30} \mathrm{~A}$ disciplinary proceeding that bans an amateur athlete from a sport may not have as its primary decision-making purpose the determination of a civil right or obligation, but it is arguable that Article 6 may still apply because the consequence of that decision determines a civil right or obligation. ${ }^{31}$ An amateur athlete may not be permitted to earn money directly from participation in the sport because of the sport's rules but may earn money from participation in the sport in another capacity, e.g. as a paid coach, which arguably adds a pecuniary element to a dispute. ${ }^{32}$ It would depend on the object or objects of the dispute.

It is by no means certain that all dispute resolution proceedings involving amateur athletes are entirely excluded from the scope of Article 6(1). In Ali Riza, the circumstances of that case, meant that the amateur football players' applications fell outside the scope of Article 6(1), but there may be other types of amateur athletes' disputes that involve the determination of civil rights and obligations and are captured. In any event, it is preferable that sports governing body procedures adopt the highest standards applicable and not adjust the applicable procedural standards to the status of those who are the subject of proceedings. It adds credibility to the process, does not discriminate and ensures that procedural safeguards consistent with fundamental human rights apply to all who are subject to the procedure.

Article 6 also provides that a tribunal must be established by law. The jurisdiction of a sports dispute resolution system in the UK is typically established by contract and implemented by a private sports governing body. The issue of whether a sports dispute forum is a tribunal established by law has yet to be substantively argued before the ECtHR and ECtHR jurisprudence regarding the interpretation of the phrase insofar as it applies to private entities exercising an adjudicatory function is limited. Generally, under ECtHR case law, it is recognised that a tribunal does not need to be integrated into the judicial machinery of a country in order for proceedings to be subject to Article 6, provided that it offers the appropriate guarantees. ${ }^{33} \mathrm{~A}$ body responsible for determining a limited number of specific disputes

\footnotetext{
${ }^{30}$ See Varnish v British Cycling Federation (t/as British Cycling) [2020] IRLR 822 (EAT); and Deliège v Ligue Francophone de Judo et Disciplines Associées ASBL (C51/96 and C191/97) [2002] 2 CMLR 65.

${ }^{31}$ See Ringeisen v Austria (No 1) (1979-1980) 1 EHRR 455; cf Le Compte that confirmed a tenuous connection or remote consequence is not sufficient but that civil rights and obligations must be the object - or one of the objects of the dispute - and the result of the proceedings must be directly decisive for such a right: (n 27) para 47.

32 See Deliège (n 30).

${ }^{33}$ X v United Kingdom (1982) 4 EHRR 188, para 53; Rolf Gustafson $v$ Sweden (1998) 25 EHRR 623, para 45
} 
may be defined as a tribunal for the purposes of Article 6 , if it provides those guarantees, for example, an arbitral tribunal. ${ }^{34}$ Specialist fora provide flexibility and expertise that can make the decision-making in certain disputes more cost effective and efficient and remove the dispute from an overburdened state justice system. ${ }^{35}$ It must, however, be a forum with the power of decision-making (e.g. have the authority to decide legal disputes with binding effects for the parties) $;{ }^{36}$ determine matters within its jurisdiction, on the basis of rules of law and after proceedings conducted in a prescribed manner ${ }^{37}$ and comply with other substantial requirements of Article 6, such as independence from the executive and impartiality. ${ }^{38}$ In that regard, the ECtHR has held that established by law covers not only the legal basis of the existence of a tribunal, but also compliance with the particular rules that govern it. ${ }^{39}$

In the sports context, whether a sports dispute resolution panel or tribunal may be considered a tribunal established by law has not received substantive consideration by the ECtHR. In Mutu and Pechstein v Switzerland ${ }^{40}$ whether the Court of Arbitration for Sport was a tribunal established by law, was not in dispute. The majority in that case were satisfied that it had the appearance of a tribunal established by law because it: emanated from a private foundation; had full jurisdiction on the basis of legal rules to determine disputes submitted to it; its awards resolved disputes in a judicial manner and could be appealed to the Swiss Federal Court; and the Swiss Federal Court recognised in its case law that CAS awards were comparable to national court judgements. ${ }^{41}$ In that regard, the majority decision in Mutu and Pechstein establishes that it is sufficient for a tribunal to have the appearance of being established by law. The issue was also not disputed in Ali Riza and Others v Turkey, ${ }^{42}$ although in that case the relevant tribunal, the Turkish Football Federation Arbitration Committee (TFF AC), was established under State legislation in contrast to the privately established

\footnotetext{
34 Lithgow and Others $v$ the United Kingdom (1986) 8 EHRR 329, para 201; Mutu and Pechstein (n 7) para 149.

35 Le Compte, Van Leuven \& De Mayer (n 27) para 51. In the UK, there is increasing encouragement for the use of certain types of alternative dispute resolution procedures before and during court proceedings: see Civil Justice Council (2018)

${ }^{36}$ Bentham $v$ the Netherlands App no 8848/80 (ECtHR, 23 October 1985), para 40.

37 Ali Riza (n 8) para 195.

38 Beaumartin v France (1995) 19 EHRR 485, para 36.

39 DMD Group v Slovakia App no 19334/03 (ECtHR, 5 October 2010), para 59.

40 (n 7).

${ }^{41}$ Mutu and Pechstein (n 7) para 149.

42 (n 8).
}

Court of Arbitration for Sport, which arguably strengthened the TFF AC's position as a tribunal established by law.

A sports dispute forum in the UK is underpinned by regulatory rules that arise under a private contract and define its jurisdiction and procedure. ${ }^{43}$ It usually exercises a decisionmaking power rather than advisory function, resolves cases in a judicial-like manner and its decisions are subject to the supervisory jurisdiction of the general courts or can be challenged under the Arbitration Act 1996 (if it is established as an arbitration procedure). Although it is arguable whether the decision of a sports dispute forum is a proper judgement comparable to those of a national court, a sports dispute resolution panel or tribunal can certainly have the appearance of a tribunal established by law even if it is not underpinned by statute. The focus then becomes whether the forum complies with all other elements of Article 6, particularly those of independence and impartiality.

Independence and impartiality are essential elements of Article 6. ECtHR jurisprudence establishes that independence involves a consideration of all the relevant circumstances, including: the manner of appointment of decisionmakers; the duration of the decision-maker's term; the guarantees against outside pressure; and the appearance of independence (i.e. the standing of the tribunal and its procedure). ${ }^{44}$ An impartial tribunal is organised with the absence of prejudice or bias. For the purposes of Article 6, impartiality is determined according to a subjective test and an objective test. ${ }^{45}$ The subjective test considers whether the personal views and conduct of the decision-maker in a particular case demonstrated bias and partiality. The objective test considers whether the court offered guarantees sufficient to exclude legitimate doubt about partiality in an external observer, e.g. through the composition of the court or its freedom from influence. ${ }^{46}$ Objective impartiality and independence are closely linked and in some cases may be considered together. ${ }^{47} \mathrm{~A}$ tribunal must be independent and impartial both in substance and in appearance. ${ }^{48}$ The next section considers in further detail the two ECtHR cases that have discussed the requirements of independence and impartiality

\footnotetext{
${ }^{43}$ Sports governing bodies in the United Kingdom are independent of government and not part of a governmental system of regulation, although the system of rules that a sports governing body implements has been described as "a legislative code": Enderby Town Football Club Ltd $v$ The Football Association Ltd and Anor [1971] 1 All ER 215, 219.

${ }^{44}$ Mutu and Pechstein (n 7) para 140 and cases cited in that paragraph.

${ }^{45}$ Mutu and Pechstein (n 7) paras 141-142.

46 Ibid.

${ }^{47}$ Mutu and Pechstein (n 7) para 144.

48 Gautrin v France (n 26) para 58; Thaler v Austria (2005) 41 EHRR 33, para 30.
} 
of dispute resolution systems in the sports industry at an international and national level, namely: Mutu and Pechstein $v$ Switzerland; and Ali Riza and Others $v$ Turkey.

\subsection{Mutu and Pechstein v Switzerland}

Mutu and Pechstein considered the lawfulness under Article 6 of disciplinary proceedings brought against two athletes: one a professional footballer and the other a professional speed skater. Mr Adrian Mutu was dismissed by his (then) employer Chelsea Football Club (Chelsea FC) after an antidoping sample that Mr Mutu provided tested positive for cocaine. A dispute ensued between Chelsea FC and Mr Mutu regarding whether the player had breached his employment contract without just cause within the meaning of Article 21 of the FIFA Regulations for the Status and Transfer of Players 2001 (FIFA RSTP 2001). The dispute was submitted for arbitration to the Football Association Premier League Appeals Committee (FAPLAC), which decided in April 2005 that the player had breached his contract. Mr Mutu appealed the FAPLAC decision to the Court of Arbitration for Sport (CAS). CAS upheld the decision.

On the basis that Mr Mutu had been held to have breached his employment contract, Chelsea FC brought a breach of contract claim in the FIFA Dispute Resolution Chamber, seeking damages for breach of contract. The Club succeeded and was awarded the sum of $€ 17,173,990.00$ in accordance with Article 22 of the FIFA RSTP 2001. Mr Mutu appealed the decision to CAS, which dismissed the appeal. In September $2009 \mathrm{Mr}$ Mutu brought an application in the Swiss Federal Court to annul the CAS arbitral award in respect of the damages amount on a number of grounds, one of which was that CAS had not provided sufficient guarantees of independence and impartiality. ${ }^{49} \mathrm{Mr}$ Mutu claimed that one of the CAS arbitrators had failed to disclose that the arbitrator's law firm represented the interests of the controlling owner of Chelsea FC. Furthermore, another of the CAS panel members had presided over the CAS arbitral panel that had issued the first award in the dispute in favour of Chelsea FC. As a consequence, Mr Mutu argued that he had not received a fair hearing before an independent and impartial arbitral tribunal. The Swiss Federal Court disagreed, concluding in the circumstances that there were no justifications for finding both arbitrators lacked independence or impartiality. $\mathrm{Mr}$ Mutu subsequently filed a claim against Switzerland in the ECtHR, alleging that he had been denied a fair hearing under Article 6(1) of the ECHR.

Ms Claudia Pechstein was a multiple speed skating Olympic Champion who in 2009 was held by the

\footnotetext{
49 Grounds for challenging a CAS award are set out in s 190 of the Private International Law Act (Switzerland).
}

International Skating Union (ISU) to have used a prohibited method of blood doping. A two-year period of ineligibility followed. Ms Pechstein appealed the decision to CAS challenging the research and evidence that set the parameters for permissible haematological values, and asserting that a number of factors, including a genetic predisposition to high haematological values may have caused the test result. Ms Pechstein also requested a public hearing, but her request was denied and the hearing was held in private. The CAS upheld the ISU decision. Ms Pechstein appealed to the Swiss Federal Court to set aside the arbitral award on a number of grounds, including: the method for appointment of the arbitrators; comments made in another context by the presiding president of the CAS panel that he took "a hard line" on doping issues; and the absence of a public hearing. Her application was dismissed by the Swiss Federal Court whereupon Ms Pechstein filed a claim in the ECtHR, alleging that her right to a fair hearing under Article 6(1) had been infringed. Both Mr Mutu and Ms Pechstein claimed that the CAS could not be regarded as an independent and impartial tribunal. Ms Pechstein also claimed that she had been denied a public hearing. The majority in the ECtHR decision dismissed Mr Mutu's claim and upheld Ms Pechstein's claim that she was denied a fair hearing. It awarded Ms Pechstein damages of $€ 8,000.00$ in respect of the infringement; the arbitral decision remained extant.

The decision is important in the context of sports dispute resolution design. First, it confirms that a dispute resolution system established in the sports industry as an arbitral procedure may in certain cases be characterised as compulsory arbitration and accordingly must afford the parties the safeguards secured by Article 6 of the ECHR. In Ms Pechstein's case, the arbitration agreement was outlined in the ISU Regulations. Although Ms Pechstein was not required by general law to submit to arbitration, the law that applied was the ISU Regulations. The choice available to Ms Pechstein was to accept the arbitration clause or not accept the clause and face the prospect of not earning a living from her chosen sport. ${ }^{50}$ On this basis, the Court concluded that Ms Pechstein had not accepted the arbitration clause freely and unequivocally, and the proceedings before CAS were properly characterised as compulsory arbitration proceedings. ${ }^{51}$ The questions raised in Ms Pechstein's case involved disputed facts, and the sanction imposed carried a degree of stigma that was likely to adversely affect Ms Pechstein's professional honour and reputation. ${ }^{52}$ Accordingly, in those circumstances denying a public hearing infringed Article 6(1).

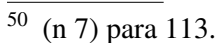

51 (n 7) para 115.

52 (n 7) para 182
} 
Mr Mutu's situation, on the other hand, differed because the applicable FIFA regulations did not impose arbitration but left the choice of dispute settlement mechanism to the contractual freedom of the clubs and players. Although $\mathrm{Mr}$ Mutu argued that: all players at his club were obliged to accept the clause; it was commonplace in the football industry to use arbitration; and it was only a notional possibility to bring the dispute to a national court, the ECtHR held that, on the basis of the evidence presented, Mr Mutu had freely accepted the CAS jurisdiction. Nonetheless, the fact Mr Mutu had challenged the arbitrator's independence and impartiality during the proceedings demonstrated that he had not waived his right to have the case heard by an independent and impartial tribunal because he had not unequivocally accepted the CAS jurisdiction. The arbitration proceedings to which Mr Mutu and Ms Pechstein were each a party needed to comply with Article 6 of the ECHR.

Secondly, the ECtHR confirmed that CAS is a judicial authority independent of the parties. CAS is a private adjudicatory forum, initially established by the International Olympic Committee and organised by ICAS, the International Council of Sports Arbitration. Ms Pechstein argued that the CAS lacked structural independence because of the method by which it was funded and the appointment mechanism for arbitrators to the CAS Panel List applicable at the time that her proceedings were heard. CAS is funded by entities attached to the Olympic Movement and by arbitration fees. Drawing an analogy with the financing of national courts, the ECtHR concluded that CAS did not lack independence or impartiality solely on account of the manner by which it was financed.$^{53}$ Regarding the appointment mechanism for CAS arbitrators to the CAS Panel List, the ECtHR acknowledged that at the relevant time, organisations which were likely to be involved in disputes with athletes had real influence over the mechanism for appointment of arbitrators, but it could not conclude that the arbitrators were objectively or subjectively biased. ${ }^{54}$ There was no breach of Article 6(1) on the basis of structural bias.

\subsection{Ali Riza and Others v Turkey}

The second case of Ali Riza and Others $v$ Turkey considered whether dispute resolution bodies constituted at a national level in football in Turkey were independent and impartial for the purposes of Article 6(1) of the ECHR. The case involved five applications: an employment-related dispute between a professional player and a professional club; a

\footnotetext{
53 (n 7) para 151.

${ }^{54}$ Note the view of the dissenting judgement that the CAS appointment mechanism showed CAS had no appearance of independence: (n 7) dissent, para 11.
}

dispute relating to a football referee whose position as referee was downgraded; and a dispute involving three amateur players who were subject to disciplinary proceedings in relation to allegations of match-fixing. The cases involving the amateur players were rejected owing to the absence of any pecuniary effect for the amateur players, with the consequence that the disciplinary proceedings did not involve the determination of a civil right sufficient to engage Article $6 .{ }^{55}$ The ECtHR limited its substantive consideration to the cases of the professional football player, Mr Ali Riza, and the referee because these cases involved the applicants' employment interests and consequently a determination of a civil wrong sufficient to bring the claims within the scope of Article 6(1). This journal article focuses on Mr Riza's claim.

The player, Mr Ali Riza, had been employed in the top Turkish professional league by the club, Trabzonspor Kulübü Dernegi. In January 2008, Mr Riza left the club and returned home to the UK, 18 months into a contract that ran between January 2006 and July 2008. The dispute that followed arose from the termination of his contract. The club alleged that he had left without notice, missed training without permission and failed to return. It fined him the equivalent of $€ 109,523.00$. The club lodged a claim in the Turkish Football Federation's Dispute Resolution Chamber (TFF DRC), seeking damages of $€ 153,670.00$ for wrongful termination of contract, payment of the fine and a transfer ban to prevent Mr Riza taking up employment with another club. Mr Riza counterclaimed, alleging that the club had failed to pay him for more than four months, and seeking arrears of salary for the months of January 2008 to April 2008, match appearance fees for the first part of the 2007/2008 season, and match appearance fees that he would have received had the contract not been terminated .

The TFF DRC upheld the club's claim and dismissed $\mathrm{Mr}$ Riza's counterclaim. It ordered the player to pay the fine, pay damages for wrongful termination and suspended the ability of the player to sign for another club for four months. $\mathrm{Mr}$ Riza appealed to the Turkish Football Federation Arbitration Committee (TFF AC), which partly allowed the objection. It upheld the TFF DRC's finding that Mr Riza had wrongfully terminated the contract, but reduced the amount Mr Riza had to pay to $€ 61,596.00$ and annulled the sanction which prevented Mr Riza from signing for another club. Mr Riza endeavoured to appeal to the CAS, which declined jurisdiction. He appealed the CAS decision to the Swiss Federal Court, which dismissed the appeal. In 2011, Mr Riza then brought a challenge in the ECtHR, alleging an infringement of Article 6(1) of the ECHR.

Mr Riza argued that the proceedings before the TFF AC were compulsory arbitration proceedings and infringed

\footnotetext{
$\overline{55 \text { (n 8) paras }} 155-156$.
} 
Article 6(1) because the TFF AC was not an independent and impartial tribunal as required under the civil limb of Article 6(1). On the compulsory arbitration issue, the ECtHR, drawing on Mutu and Pechstein, agreed that proceedings before the TFF AC were compulsory arbitration proceedings because a national law in force in Turkey at the relevant time provided for the compulsory jurisdiction of the TFF AC in football disputes. There was no option to bring a dispute to a civil court. Accordingly, proceedings before the TFF AC had to provide the procedural safeguards afforded under Article $6 .{ }^{56}$

To understand the arguments relating to the TFF AC's lack of independence and impartiality, it is useful to understand the Turkish Football Federation (TFF)'s governance structure. At the relevant time, the TFF was established by national law as an autonomous entity, governed by private law principles, with a separate legal personality to regulate all aspects of professional and amateur football in the country. The TFF's main bodies were the Congress, Board of Directors and the Legal Committees, of which the TFF AC was the highest judicial appellate body. The TFF's governance structure was outlined in further detail in the TFF Statutes. The Congress was the TFF's principle decision-making body and adopted the TFF Statutes, which prescribed how the organisation operated. The Congress also appointed the Board of Directors which in turn issued Directives governing the functions of various bodies, and the administration and discipline of football (for example, the Arbitration Directive). The Board of Directors also had the power to appoint the TFF AC members and determine the TFF AC members' remuneration, expenses and allowances payments. The duration of appointment of the TFF AC's members was the same as that of the Board. TFF AC members had a duty to decide cases in an independent and impartial manner as prescribed under the national law. Of importance, was the fact that under the relevant national law and the TFF's Arbitration Directive, the TFF AC's decisions were final and could not be challenged to the general court, even by way of challenge similar to a domestic arbitration award.

Mr Riza argued that the TFF AC lacked independence and impartiality because in contractual disputes between a club and player, the players and clubs did not have equal influence in the TFF AC composition. Only a small number of delegates represented the players' interests in the Congress; the majority represented the interests of the clubs. As the Congress elected the Board of Directors which in turn elected the TFF AC members, the Board of Directors and the TFF AC were effectively controlled and managed by the clubs and it could be argued that the TFF AC had an implicit bias towards clubs. In addition, the TFF AC members had

56 (n 8) para 181. the same term of office as the Board of Directors; the internal rules of procedure were determined by the Board of Directors; there were no procedural safeguards to protect TFF AC members from outside pressures; the TFF AC was located in the TFF headquarters and TFF staff carried out administration and secretarial work for the TFF AC; and the TFF AC had no separate legal personality or budget.

The ECtHR upheld Mr Riza's claim. In the majority's view, the manner of appointment of TFF AC members did not in itself undermine independence and impartiality provided that once appointed the TFF AC members were not subject to pressure, did not receive instructions from the Board of Directors and were able to perform their duties with complete independence. ${ }^{57}$ As there was no evidence that the Board of Directors had instructed the TFF AC members to perform their duties in a particular way, the ECtHR considered the procedural safeguards in place to allow members to decide a case independently. It concluded that there were strong organisational and structural ties between the Board of Directors and the TFF AC that indicated a significant level of influence of the Board of Directors over the TFF AC. These features included the following: the Congress and the Board of Directors generally consisted of those representing the interests of the football clubs; TFF AC members were not required to disclose circumstances affecting their independence and impartiality; there was no specific procedure for the parties to a dispute to challenge a TFF AC member's appointment; the remuneration amounts were determined by the Board of Directors (although drawing on Mutu and Pechstein, the ECtHR pointed out that the financial arrangements were not on their own sufficient to conclude that there was a lack of independence or impartiality); the term of the TFF AC members was "unduly aligned" with the term of the Board of Directors; TFF AC members were not immune to legal action arising in connection with a discharge of their duties; and TFF AC members were not bound by professional rules of conduct and were not required to take an oath or make a declaration before taking up their duties. ${ }^{58}$

The ECtHR then considered whether the TFF AC consisted of members who could be regarded as objectively or subjectively independent and impartial when compared with the entities that were likely to be a party to a dispute. It concluded that in contractual disputes between clubs and players, the composition of the Congress and Board of Directors as favouring clubs may be considered to "tip the balance in favour of clubs" in proceedings between a player and a club before the TFF AC. ${ }^{59}$ Decisions potentially set a precedent which could influence other disputes

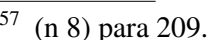

58 (n 8) paras 210-216.

59 (n 8) para 219.
} 
of a similar nature between clubs and players. In regulatory disputes, structural deficiencies such as the vast powers of the Board of Directors over the TFF AC in the absence of strong safeguards protecting the TFF AC members from outside pressure meant there was an absence of independence and impartiality. ${ }^{60}$

For these reasons, the ECtHR concluded that the TFF AC was not organised in a way so as to ensure its independence from the Board of Directors, and national law provided no safeguards to protect members of the TFF AC from outside pressure and enable it to perform duties with independence. ${ }^{61}$ It upheld the applicants' complaints and determined that an infringement of Article 6(1) of the ECHR had occurred. It awarded $€ 12,500.00$ to each applicant in respect of non-pecuniary damage. ${ }^{62}$ It did not award pecuniary damage because it could not speculate on the outcome of the proceedings had the TFF AC been independent and impartial. ${ }^{63}$

On an individual level, although the applicants won their claim to the ECtHR on different grounds in Mutu and Pechstein and in Riza, neither Ms Pechstein nor Mr Riza had the original decisions overturned or received pecuniary awards that represented their actual losses. The amounts of $€ 8,000.00$ and $€ 12,500.00$ that Ms Pechstein and Mr Riza, respectively, obtained were nominal when compared to the likely overall pecuniary loss each athlete suffered. In that regard, it may be viewed as a pyrrhic victory for the individual athletes. The cases highlight some important features that are relevant to the independence and impartiality of a sports dispute resolution forum and these are discussed in the following section.

\subsection{Independence and impartiality in sports dispute proceedings}

Mutu and Pechstein and Riza are important cases in the context of sports dispute resolution design. Both cases confirm that a regulatory sports dispute resolution system that is designed as an arbitration procedure may, in certain circumstances, be characterised as compulsory arbitration proceedings. If compulsory arbitration, then proceedings must guarantee the safeguards secured by Article 6(1) of the ECHR, including the right to a public hearing. Riza, in particular, is extremely useful for highlighting the factors for

\footnotetext{
$\overline{60 \text { (n 8) para } 223 .}$

61 (n 8) para 241.

62 (n 8) para 249.

63 (n 8) para 246. Note the partly concurring partly dissenting decision of Judge Bosnjak who pointed to a line of existing authority which permits the ECtHR to speculate on outcomes in certain circumstances and award an amount for pecuniary loss: (n 8) paras 16-19.
}

consideration when seeking to establish an independent and impartial judicial structure in sport. These include:

- The mechanism for appointing a list of panel members to a specific dispute resolution body must provide for a balanced panel membership. Although a feature that is not on its own sufficient to found an argument that a panel lacks independence and impartiality, the requirement to ensure that there is balanced membership is important. When appointing members to a panel list, consideration needs to be given to the types of disputes that a panel member will likely consider and the interests supporting the appointment of those individual members so that the panel composition may not be perceived as unduly favouring one side of the dispute over the other. Advertising panel roles to appoint panel members from a wide recruitment pool can be a way to provide a balanced and diverse independent panel membership.

- Panel members must be able to undertake their decisionmaking free from external influence. The types of features that can protect a dispute resolution forum from allegations that panel members are under the influence of other entities within the sports governing body's structure include: an immunity from legal action (e.g. a procedural rule that indemnifies a panel member if legal action arises from a decision); assurance that panel members are not instructed how to decide a case; lengthy terms of tenure for panel members that do not coincide with appointments to other controlling entities within the governance structure; a requirement that panel members make a declaration of independence prior to joining the list; a requirement that panel members hold membership to another professional body, e.g. a legal professional body.

- A procedure for challenging individual panel appointments and disclosure is required. A procedural rule that requires an individual panel member to disclose circumstances affecting their independence and impartiality and a specific procedure for the parties to challenge a panel's appointment can assist with demonstrating the independence and objective impartiality of a particular panel.

- Protection from influence for individual panel members is required. Unlike judges who have legal immunity for their decision-making, panel members appointed to adjudicate sports dispute proceedings do not have legal immunity from civil or criminal action arising from their decision-making. If the dispute resolution body is established as an arbitral panel or tribunal with a seat in England and Wales, then arbitrators may be able to benefit from the protections afforded under s 29 of the Arbitration Act 1996. Some sports governing bodies may be in the financial position to provide indemnity insurance cover for panel members. A requirement that panel mem- 
bers have their own professional indemnity insurance or utilising an appointing body that has professional indemnity insurance may also provide the necessary protection.

So far, Mutu and Pechstein and Riza have not been subject to consideration in national courts in the UK, although there have been some cases that have challenged the structure of a sports dispute resolution forum under Article 6 or the common law doctrine of apparent bias.

\section{Common law challenges to sports dispute resolution systems}

Stretford v Football Association Ltd and Anor ${ }^{64}$ is at present the only case to substantively consider the alleged infringement of Article 6 in a sports dispute resolution procedure, specifically an arbitral procedure. In that case, Mr Stretford, a players' agent, applied for and was granted a Football Association (FA) players' agent's licence in April 2002 under the licensing regime for players' agents that existed at the time. The face of the licence recorded that, "the holder of this licence agrees to abide by the rules and regulations of FIFA, the Football Association, the FA Premier League and the Football League". The FA Rules are published yearly in the FA Handbook and contain an arbitration agreement in Rule K.

In June 2005, the FA issued disciplinary proceedings against Mr Stretford. Before the proceedings could be heard, $\mathrm{Mr}$ Stretford filed a High Court claim alleging, amongst other things, that the disciplinary proceedings would not comply with Article 6 of the ECHR. In its defence, the FA requested a stay of the High Court proceedings on the basis that Rule $\mathrm{K}$ required any dispute regarding the proceedings to be referred to arbitration. In defence of the stay application, Mr Stretford argued that he was not bound by the arbitration agreement contained in Rule $\mathrm{K}$ on the grounds that, inter alia: it was not incorporated into a contract between him and the FA; and it was "null and void" under s 9(4) of the Arbitration Act 1996 because it conflicted with Article 6 of the ECHR. ${ }^{65} \mathrm{Mr}$ Stretford asserted that Rule K did not comply with Article 6 because the arbitrator appointment mechanism called into question the independence of the arbitrators and Rule K prohibited public disclosure of the award.

\footnotetext{
64 Stretford v Football Association Ltd [2006] EWHC 479 (Ch); decision upheld on appeal in Stretford v Football Association Ltd [2007] Bus LR 1052 (CA).

65 Section 9(4) of the Arbitration Act 1996 provides that: "On an application under this section the court shall grant a stay unless satisfied that the arbitration agreement is null and void, inoperative, or incapable of being performed."
}

The High Court disagreed with Mr Stretford and granted the FA a stay of proceedings under the Arbitration Act 1996, whereupon Mr Stretford appealed to the Court of Appeal. The Court of Appeal held that Rule K was incorporated into the contract between the FA and Mr Stretford and that by agreeing to Rule K: both parties waived their right to a hearing before the courts (except in accordance with the Arbitration Act 1996); and had waived the right to a public hearing. ${ }^{66}$ On the issue of whether Rule K conflicted with Article 6 of the ECHR, the Court confirmed that when the parties voluntarily enter into an arbitration agreement they waive their rights under Article $6 .{ }^{67}$ To be an effective waiver, however, it must be without compulsion or constraint, and not run contrary to the public interest. ${ }^{68}$ On the facts of the case at hand, the Court of Appeal concluded that Rule K was "not in any sense required by law or compulsory." ${ }^{69}$ It noted that: ${ }^{70}$

"an arbitration clause has become standard in the rules of sporting organisations like the FA. The rules regulate the relationship between the parties, which is a private law relationship governed by contract... Clauses like Rule K have to be agreed to by anyone, like Mr Stretford, who wishes to have a players' licence, but it does not follow that the arbitration agreement contained in them was required by law or compulsory. To strike down clauses of this kind because they were incompatible with Article 6 on that basis would have a far-reaching and, in our opinion, undesirable effect on the use of arbitration in the context of sport generally."

The Court of Appeal stated that the ECtHR jurisprudence did not explain the meaning of "constraint" and that existing principles of the common law and equity were relevant, e.g. principles of duress, undue influence, mistake and the requirement for onerous and unusual terms of the contract to be brought to the attention of the other party. ${ }^{71}$ It concluded that English Law fully protected parties who were compelled to enter into an arbitration agreement because of "constraint". It also concluded that there was no issue regarding constraint in $\mathrm{Mr}$ Stretford's case. ${ }^{72}$ Furthermore, there was no suggestion that Rule $\mathrm{K}$ was counter to any

\footnotetext{
66 Stretford (CA) (n 64) para 66.

67 The Court referred to $X v$ Federal Republic of Germany (App No 1197/61) [1962] 5 YB 88; $R v$ Switzerland (1987) 51 DR 83; Deweer $v$ Belgium (1980) 2 EHRR 439; and Nordström-Janzon and Nordstöm-Lehtinen v The Netherlands (1996) 87 ADR 112.

68 Deweer v Belgium (1980) 2 EHRR 439.

69 Stretford (CA) (n 64) para 49.

70 Ibid.

71 Stretford (CA) (n 64) para 53.

72 Ibid. See criticism of the finding in U Haas, (2012)
} 
important public interest; if anything, the public interest encouraged arbitration in cases of this kind. ${ }^{73}$ The Court of Appeal upheld the High Court's decision to grant a stay of legal proceedings.

In light of Mutu and Pechstein and Riza, it is very likely that proceedings under Rule $\mathrm{K}$, together with other arbitration agreements in the regulations of UK sports governing bodies, would be characterised as compulsory arbitration proceedings with the effect that Article 6 applies. ${ }^{74} \mathrm{Mr}$ Stretford was faced with the choice of accepting the arbitration clause and earning a living as a sports agent in football or not accepting Rule $\mathrm{K}$ and refraining from working as a sports agent in football. Applying Mutu and Pechstein and Riza, such a choice is not a free and unequivocal choice to agree to arbitration under Rule K.

National law has a role to play in considering whether a breach of Article 6 arises in a case concerning arbitration proceedings. ${ }^{75}$ Unlike Riza where the TFF AC's decision was final and unable to be challenged in the general court under national law, domestic sports arbitration proceedings are subject to supervision by the courts through the Arbitration Act 1996. The Arbitration Act 1996 ensures that courts can oversee the provision of a fair hearing by an impartial arbitral tribunal. ${ }^{76}$ It also provides for greater access to a court than other arbitration laws in some other countries. ${ }^{77}$ The only provisions of Article 6 not formerly met by the Arbitration Act 1996 are the requirements that: a hearing be held in public; membership of the tribunal be independent; the tribunal be established by law; and that judgement be pronounced quickly. ${ }^{78}$ The Court of Appeal in Stretford did not consider substantively whether the arbitral tribunal that was to be formed under Rule K, was a tribunal established by law. It proceeded "on the assumption that an arbitral tribunal is not a tribunal established by law, within the meaning of Article 6" and looked at whether the parties had waived Article 6 altogether, which it concluded they had. The legal basis for sports adjudicatory forums to which Article 6 applies still remains uncertain.

The common law doctrine of apparent bias has also been used to challenge the impartiality of a sports tribunal. The test for apparent bias is stated in the leading case of Porter $v$ Magill, ${ }^{79}$ and requires consideration of "whether a fair minded and informed observer, having considered the

\footnotetext{
73 Stretford (CA) (n 64) para 66.

74 N deMarco, (2018)

75 Deweer v Belgium (1980) 2 EHRR 439.

76 See Arbitration Act 1996, ss 24, 33, 67 and 68.

77 Arbitration Act 1996, ss 67, 68 and 69.

78 Stretford (CA) (n 64) para 38.

79 [2002] 2 AC 357 (HL).
}

relevant facts, would conclude that there was a real possibility of bias" ${ }^{80}$ It is considered to be in line with the ECtHR's assessment of objective impartiality. ${ }^{81}$ Issues regarding the independence of a dispute resolution procedure may be relevant to determining objective impartiality.

The test was applied in the context of sports dispute resolution procedures in Flaherty v National Greyhound Racing Club Ltd ${ }^{82}$ and McKeown v British Horseracing Authority. ${ }^{83}$ In Flaherty v National Greyhound Racing Club Ltd, a greyhound trainer challenged a decision of the National Greyhound Racing Club Limited (NGRCL) to reprimand and fine him $£ 400.00$ for administering hexamine, a prohibited performance enhancing substance, to a dog contrary to the racing rules of the NGRCL. Mr Flaherty successfully argued that the decision was invalid because one of the stewards, appointed by the NGRCL to determine whether there had been a breach of the racing rules, showed apparent bias. On appeal the Court of Appeal overturned the High Court finding on the basis that the steward's prior relationship, professional connections and views expressed at the inquiry did not, on an objective analysis, demonstrate apparent bias. Establishing apparent bias is specific to the facts of a case. It involves first ascertaining the facts on which the suggestion of bias is based; and, secondly, making an objective appraisal of those facts. ${ }^{84}$ In McKeown v British Horseracing Authority, ${ }^{85}$ the High Court rejected an argument that a horseracing disciplinary panel and appeal panel were bias. There was no evidence of actual or apparent bias and $\mathrm{Mr}$ McKeown's argument that the panels demonstrated apparent bias because the panels had reached an unreasonable conclusion or made an unreasonable finding of fact, was wrong in law. ${ }^{86}$

Apparent bias was also an issue in Modahl v British Athletic Federation (No 2), ${ }^{87}$ albeit on facts that arose prior to the adoption of the HRA 1998 and the House of Lords' decision in Porter $v$ Magill. Ms Modahl, a GB representative athlete, claimed damages from the British Athletic Federation (BAF) (as it was then known) as a result of the BAF's alleged breach of an implied contractual obligation to select members of a disciplinary committee who would be impartial and free of bias. Modahl had been subject to disciplinary proceedings following a positive drug test at an international athletics meeting in Lisbon in 1994. A disciplinary committee decided she had committed an anti-doping rule violation,

\footnotetext{
$\overline{80 \text { Ibid para } 103 .}$

${ }^{81}$ Magill (n 79) para 103.

${ }^{82}$ [2005] EWCA Civ 1117.

83 [2010] EWHC 508.

${ }^{84}$ Flaherty (n 82) para 27.

85 [2010] EWHC 508.

${ }^{86}$ McKeown (n 83) paras 327 and 335.

87 [2001] EWCA Civ 1447.
} 
a decision that was overturned on appeal on the basis of new evidence. The essence of Ms Modahl's case was that the first instance disciplinary committee was tainted by bias. The success of her damages claim relied upon finding that a contract existed between her and the BAF that contained a term in relation to disciplinary proceedings that the BAF had breached and which had caused her damage.

The Court of Appeal accepted that on the facts of the case, a contract arose between Ms Modahl and the BAF which included a term that the BAF would carry out disciplinary procedures in accordance with its rules and undertake to carry out the disciplinary process fairly. The scope of the term extended to a consideration of whether the end result of the process was fair and not in respect of each individual stage. ${ }^{88}$ As Latham $\mathrm{LJ}$ expressed, "the test is whether having regard to the course of the proceedings, there has been a fair result" ${ }^{89}$ Latham LJ acknowledged that there may be cases in which owing to corruption, bias or some other deficiency the end result may not be described as fair, however, "the question in every case is the extent to which the deficiency alleged has produced overall unfairness". ${ }^{90}$ On the facts of Modahl, the Court of Appeal concluded that the process as a whole had produced a fair result, notwithstanding apparent bias on the part of one member of the first instance disciplinary committee. ${ }^{91}$ This is consistent with the ECtHR's approach that Article 6 may be satisfied even if a first instance body does not comply with Article 6, provided proceedings are subject to a review by a judicial body that does in fact comply and has full jurisdiction to consider the law and the facts.

\section{Conclusion}

Mutu and Pechstein and Ali Riza and the other common law cases highlight the factors that secure the independence and impartiality of a dispute resolution process which is organised within a sports governing body to ensure that the proceedings are fair, namely the need for a separation between regulatory and adjudicative functions, and independent and impartial appointments to a dispute resolution panel. This is easy to achieve in larger sports governing bodies; slightly more difficult in small or medium-sized ones where resources are an issue. The cases also highlight the uncertainty surrounding the legal basis of a forum organised under the auspices of a private sports governing body that adjudicates dispute resolution proceedings to which Article

\footnotetext{
88 Ibid para 122.

89 Modahl (n 87) para 61.

90 Ibid.

91 Modahl (n 87) para 47.
}

6 applies. The legal basis for such a forum is only one aspect of whether a tribunal is established by law; the other is the requirement for the forum to comply with all other elements of Article 6, including those of independence and impartiality. It elevates the importance of sports dispute resolution proceedings being independent and impartial.

One way of resolving the issue is to underpin the entire UK sports dispute resolution system by a statutory framework that establishes a separate UK Sports Tribunal or requires all UK sports governing bodies to utilise an independent entity such as Sports Resolutions UK for dispute resolution. This would satisfy the need for independence and impartiality in dispute resolution procedures as well as remove uncertainty as to whether a forum currently in place is a tribunal established by law. Sports governing bodies should also be encouraged to agree dispute resolution procedures with those who are likely to utilise the dispute resolution system, particularly if the proceeding is an arbitration procedure.

It is difficult without auditing all sports dispute resolution systems to know just how many satisfy the minimum threshold of independence and impartiality required by Article 6 . There are some very good models of sports dispute resolution in some governing bodies, but the system as a whole is fragmented and not all sports are sufficiently wellresourced to provide the procedural guarantees or the level of independence required for a fair hearing. Furthermore, in addition to the adjudication function of sports disputes, there are other aspects of complaint handling in sport such as access to justice for sports participants, whistleblowing and investigations that have been highlighted as requiring reform. ${ }^{92}$ Now, may be the opportune time to reconsider the sports dispute resolution model in the UK.

Open Access This article is licensed under a Creative Commons Attribution 4.0 International License, which permits use, sharing, adaptation, distribution and reproduction in any medium or format, as long as you give appropriate credit to the original author(s) and the source, provide a link to the Creative Commons licence, and indicate if changes were made. The images or other third party material in this article are included in the article's Creative Commons licence, unless indicated otherwise in a credit line to the material. If material is not included in the article's Creative Commons licence and your intended use is not permitted by statutory regulation or exceeds the permitted use, you will need to obtain permission directly from the copyright holder. To view a copy of this licence, visit http://creativecommons.org/licenses/by/4.0/.

92 See Baroness Tanni Grey-Thompson DBE, Duty of Care in Sport Report to the Government (April 2017) available at < https://assets. publishing.service.gov.uk/government/uploads/system/uploads/attac hment_data/file/610130/Duty_of_Care_Review_-_April_2017_2. pdf $>$ accessed 12 November 2020; and J Anderson and N Partington, (2018) 9-10. 


\section{References}

Anderson, Prof. Jack and Partington, Dr Neil (2018), 'Duty of Care in Sport: Time For a Sports Ombudsman?' International Sports Law Review 3 - 10

Black J (1996) Constitutionalising self-regulation. Modern Law Rev 59(1):24-55

Bogg A (2018) The common law constitution at work. Modern Law Rev 81(3):509-538

Boyes S (2017) Sport in court: assessing judicial scrutiny of sports governing bodies. Public Law 363-381

Budd JW, Sojouner AJ (2017) Are voluntary agreements better? Evidence from baseball arbitration. ILR Review 70(4):865-893

Civil Justice Council, ADR Working Council Final Report (November 2018)

De Marco QC, Nick, 'The Right to a Fair Hearing in Sports' Cases: Lessons From the ECtHR's Decision in Mutu \& Pechstein' (Lawinsport, 15 October 2018) < https://www.lawinsport.com/topics/ item/the-right-to-a-fair-hearing-in-sports-cases-lessons-from-theecthr-s-decision-in-mutu-pechstein?tmpl=component\&print=1> accessed 12 November 2020

Grey-Thompson DBE, Baroness Tanni, Duty of Care in Sport Report to the Government (April 2017) available at $<$ https://assets. publishing.service.gov.uk/government/uploads/system/uploads/
attachment_data/file/610130/Duty_of_Care_Review_-_April_ 2017 2.pdf $>$ accessed 12 November 2020

Haas U (2012) Role and application of article 6 of the european court of human rights in CAS procedures. Int Sports Law Rev 3:43-60

Neuberger RHLD (2015) Arbitration and the rule of law. Arbitration 81(3):276-287

Rigozzi A (2010) Challenging awards of the court of arbitration for sport. J Int Dispute Settl 1(1):217-265

Rogers NH et al (2013) Designing systems and processes for managing disputes. Wolters Kluwer Law \& Business, New York

Tyler TR (2009) Governing pluralistic societies. Law Contemp Probl $72: 187-191$

Tyler T (2000) Social justice: outcome and procedure. Int J Psychol 35(2):117-125

van der Harst M (2016) "Enforcement of CAS Arbitral Awards by National Courts \& the Effective Protection of EU Law" in C Paulussen et al (eds) Fundamental Rights in International and European Law TMC Asser Press, The Netherlands

Weston MA (2017) Private sport self-policing and the deficiencies of internal reporting systems. Univ St Thomas Law J 13(2):434-458

Publisher's Note Springer Nature remains neutral with regard to jurisdictional claims in published maps and institutional affiliations. 